Utah State University

DigitalCommons@USU

\title{
Linking Sportfishing Trip Attributes, Participation Decisions, and Regional Economic Impacts in Lower and Central Cook Inlet,
}

\author{
Alaska \\ Charles Hamel \\ Utah State University \\ Mark Herrmann \\ S. Todd Lee \\ Keith R. Criddle \\ Utah State University \\ Hans T. Geier
}

Follow this and additional works at: https://digitalcommons.usu.edu/eri

\section{Recommended Citation}

Hamel, Charles; Herrmann, Mark; Lee, S. Todd; Criddle, Keith R.; and Geier, Hans T., "Linking Sportfishing Trip Attributes, Participation Decisions, and Regional Economic Impacts in Lower and Central Cook Inlet, Alaska" (2001). Economic Research Institute Study Papers. Paper 214.

https://digitalcommons.usu.edu/eri/214

This Article is brought to you for free and open access by the Economics and Finance at DigitalCommons@USU. It has been accepted for inclusion in Economic Research Institute Study Papers by an authorized administrator of DigitalCommons@USU. For more information, please contact digitalcommons@usu.edu.

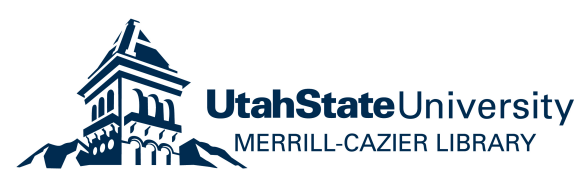


Economic Research Institute Study Paper

ERI \#2001-01

LINKING SPORTFISHING TRIP ATTRIBUTES, PARTICIPATION

DECISIONS, AND REGIONAL ECONOMIC IMPACTS IN

LOWER AND CENTRAL COOK INLET, ALASKA

by

CHARLES HAMEL

North Pacific Fishery Management Council

Anchorage, AK 99501-2252

MARK HERRMANN

Department of Economics

University of Alaska Fairbanks

Fairbanks, AK 99775-6080

S. TODD LEE

National Marine Fisheries Service

Alaska Fishery Science Center

7600 Sand Point Way NE, Bldg 4

Seattle, WA 98115

KEITH R. CRIDDLE

Department of Economics

Utah State University

3530 Old Main Hill

Logan, UT 84322-3530

HANS T. GEIER

Department of Natural Resource Management

University of Alaska Fairbanks

Fairbanks, AK 99775-7580

January 2001 


\title{
LINKING SPORTFISHING TRIP ATTRIBUTES, PARTICIPATION \\ DECISIONS, AND REGIONAL ECONOMIC IMPACTS IN

\author{
LOWER AND CENTRAL COOK INLET, ALASKA
}

\author{
Charles Hamel \\ North Pacific Fishery Management Council \\ Anchorage, AK 99501-2252 \\ Mark Herrmann \\ Department of Economics \\ University of Alaska Fairbanks \\ Fairbanks, AK 99775-6080 \\ S. Todd Lee \\ National Marine Fisheries Service \\ Alaska Fishery Science Center \\ 7600 Sand Point Way NE, BIdg 4 \\ Seattle, WA 98115 \\ Keith R. Criddle \\ Department of Economics \\ Utah State University \\ 3530 Old Main Hill \\ Logan, UT 84322-3530 \\ Hans T. Geier \\ Department of Natural Resource Management \\ University of Alaska Fairbanks \\ Fairbanks, AK 99775-7580
}

The analyses and views reported in this paper are those of the author(s). They are not necessarily endorsed by the Department of Economics or by Utah State University.

Utah State University is committed to the policy that all persons shall have equal access to its programs and employment without regard to race, color, creed, religion, national origin, sex, age, marital status, disability, public assistance status, veteran status, or sexual orientation.

Information on other titles in this series may be obtained from: Department of Economics, Utah State University, 3530 Old Main Hill, Logan, Utah 84322-3530.

Copyright (C) 2001 by Keith R. Criddle. All rights reserved. Readers may make verbatim copies of this document for noncommercial purposes by any means, provided that this copyright notice appears on all such copies. 


\title{
LINKING SPORTFISHING TRIP ATTRIBUTES, PARTICIPATION
}

DECISIONS, AND REGIONAL ECONOMIC IMPACTS IN

LOWER AND CENTRAL COOK INLET, ALASKA

\author{
Charles Hamel, Mark Herrmann, S. Todd Lee, Keith R. Criddle, Hans T. Geier
}

\begin{abstract}
Forecasts of the regional economic impacts of changes in the demand for recreation occasioned by regulatory changes, changes in the quality of the recreation experience, or changes in average trip costs require a model that links changes in these trip attributes to individual participation decisions and population participation rates. The probability that an individual will take a particular recreational trip is described using a nonlinear random effects probit model based on variable trip attributes and individual economic and demographic characteristics. These conditional individual probabilities are transformed into predictions of changes in total recreation demand using a simulation-based sample enumeration method. The regional impacts associated with ensuing changes in primary and secondary expenditure patterns are elucidated with a stand-alone recreation-sector module linked to a regionally adjusted zip code-level input-output model. Because the participation model allows for nonconstant marginal utility, primary and secondary impacts exhibit nonlinear responses to variations in trip attributes. The modeling approach is demonstrated in an application to the saltwater sport fisheries for Pacific halibut and salmon in Lower and Central Cook Inlet, Alaska.
\end{abstract}




\section{LINKING SPORTFISHING TRIP ATTRIBUTES, PARTICIPATION \\ DECISIONS, AND REGIONAL ECONOMIC IMPACTS IN \\ LOWER AND CENTRAL COOK INLET, ALASKA ${ }^{\mathrm{a}}$}

\section{Introduction}

The lure of world-class fresh and saltwater sportfishing opportunities makes Alaska's Kenai Peninsula one of the state's most visited regions. This study examines the regional economic impacts of expenditures related to the saltwater sport fisheries for Pacific halibut (Hippoglossus stenolepis), and chinook (Oncorhynchus tshawytscha) and coho $(O$. kisutch) salmon that take place lin the marine waters of Lower and Central Cook Inlet. Most of these trips originate from road-accessible segments of the western shoreline of the Kenai Peninsula. In addition to non-monetary benefits enjoyed by visiting and resident anglers, sportfishing contributes to the economic well-being of Kenai Peninsula communities as infusions of new money filter through tourism related businesses and circulate within local economies.

The decision to take a sportfishing trip is based on the expectation that the benefits of taking the trip will exceed the associated costs. Consequently, an understanding of how that decision depends on individual demographic characteristics and attributes of the recreation experience allows prediction of how angler behavior will change in response to changes in trip attributes. For example, changes in fish stock abundance that affect catch rates or regulatory measures that affect bag and possession limits will be perceived by anglers as changes in the attribute bundle associated with their fishing trip. By expressing the likelihood that alternative fishing trips will be taken in probabilistic terms, we can develop confidence bounds around estimates of changes in participation rates and associated changes in regional expenditures.

Examples of recent policy initiatives that highlight the need for regional impact analyses to account for the contribution of recreation activities include: damage assessments associated with the S.S. Glacier Bay and S.S. Exxon Valdez oil spills; potential risks associated with outer continental shelf petroleum development lease sales adjacent to prime commercial and recreational fishing grounds in Lower Cook Inlet and the Gulf of Alaska; and, management decisions to determine the allocations of allowable catches between commercial, sport, and subsistence fishers. Because oil exploration, development, and production activities in Cook Inlet could affect the productivity of adjacent fishing grounds and the

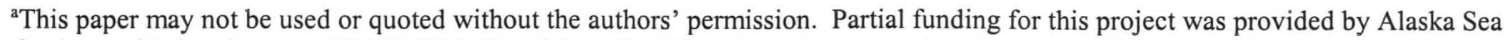
Grant with funds provided under grant 98-403 R14-17 and from the Minerals Management Service through the University of Alaska Coastal Marine Institute project 12-35-0001-30661 task order 14196. The views expressed herein are those of the authors and do not necessarily reflect those of the institutions or agencies with which they are affiliated.
} 
quality of recreational activities, economic impact analyses are required to demonstrate the range of potential adverse impacts to communities (Northern Economics 1990; Cohen 1993; MMS 1995; Herrmann et al. 2000). Another example is the allocation of Pacific halibut between commercial fishermen and sportfishing charterboat operators. Sportfishing in Alaska has increased considerably in the last few decades. Total purchases of fishing licenses have increased from 90,565 in 1961 to 431,894 in 1997. Over the same period, sportfishing catches of Pacific halibut have increased from less than $2 \%$ to $18 \%$ of total removals. Because Pacific halibut is a fully subscribed fishery with an overall limit on allowable removals, increases in sport catches necessitate concomitant reductions in commercial harvests. Such allocation decisions are subject to statutory and regulatory requirements to consider the effect on net benefits to the nation and the impact on small entities, including communities and small businesses. ${ }^{1}$ Estimates of the magnitude of consumer and producer surpluses and associated regional economic impacts are necessary for formal compliance with these requirements (Herrick et al. 1994).

The commercial and sport fisheries of Lower and Central Cook Inlet both contribute to the economic well being of residents of the Kenai Peninsula, Alaska, and the nation. Economic aspects of the commercial halibut fishery have been subject to considerable analysis (e.g. Crutchfield and Zellner 1962; Lin et al. 1988; NPFMC 1991; Homans 1993; Criddle 1994; Herrmann 1996; NRC 1999; Herrmann 2000). Economic aspects of Alaska's commercial salmon fishery have been examined at a similar level of detail (e.g. Herrmann 1993, 1994; Herrmann and Greenberg 1994). In contrast, there has been little formal analysis of Alaska's marine recreational fisheries. Coughenower (1986) provides a qualitative description of the halibut guide/charter fishery. Jones and Stokes (1987) provide a small-sample estimate of the consumer surplus associated with halibut and salmon sportfishing. Northern Economics (1990) provides an estimate of the economic impact of the S.S. Glacier Bay oil spill that includes a qualitative

\footnotetext{
${ }^{1}$ Regulatory guidelines for implementation of the Magnuson-Stevens Fishery Conservation and Management Act require that an attempt be made to assess the net economic benefits to the nation of all management actions that affect federally managed fisheries. The Regulatory Flexibility Act requires that the economic impact that proposed federal regulations would have on small entities be assessed in advance of management action. While these requirements do not specify the methodologies to be used in meeting statutory and regulatory analysis requirements, recent court decisions have set aside management actions based on ad hoc or informal economic assessments.
} 
discussion of sportfishing benefits. Our study raises the level of sportfishing analysis closer to that available for the commercial fishery. We do so using an econometric model of the determinants of individual participation decisions, a simulation procedure to aggregate across individual decisions and estimate total sportfishing effort, and a regional input-output model that describes primary and secondary expenditure patterns. This approach results in a behaviorally based integrated model of the regional economic impacts of changes in the demand for sportfishing occasioned by, for example, management actions, environmental damage, or natural fluctuations in the abundance of the target species and substitute target species.

\section{Data and Models}

The participation and regional impact models rely on data collected by a postal survey of a random sample of 4,000 anglers who purchased an Alaskan sportfishing license in 1997. The survey solicited socioeconomic and catch data, detailed information regarding expenses incurred on recent salmon and halibut fishing trips, and stated preferences for hypothetical trips. In addition to expenditures directly related to fishing, respondents were also asked to report other trip expenses including transportation and lodging costs. Overall response to survey exceeded $70 \%$. The survey design, sample frame, and responses are described in Lee et al. (1999). Herrmann et al. (2000) summarizes the survey results and crossvalidates them with common elements from the Alaska Department of Fish and Game statewide sportfishing harvest survey (ADF\&G 1998).

Attributes that affect participation in Lower and Central Cook Inlet saltwater sportfishing trips include the number and species of fish caught (including retained and released fish), average catch weight, and trip cost. On an average trip, Alaskans caught 1.71 halibut, 0.19 chinook salmon, and 0.06 coho salmon weighing $34.2,28.3$, and 10.6 pounds each, respectively. The mean nonresident trip included catches of 2.43 halibut, 0.14 chinook, 0.31 coho, and average fish weights of 42.7, 30.9, and 9.6 pounds, respectively. 
The regional economic impact of sportfishing depends on the number of participants and their expenditure patterns. We grouped recreational fishers into categories because reported expenditures varied substantially across participant origins and sportfishing modes. The residency categories were: Kenai Peninsula Borough residents (local); other Alaskan residents (non-local Alaskan); and, other US citizens (nonresident). The sportfishing modes were: fishing from shore (shore); fishing from a vessel hired for the trip (charter); and, fishing from a vessel that is personally owned or otherwise made available to the trip taker without payment of a rental fee (private). Thus, we model nine distinct expenditure patterns. Mean transportation and living expenses for local residents and other Alaskans ranged between $\$ 30.41$ and $\$ 75.66$ per day, and from $\$ 62.99$ to $\$ 103.87$ for nonresidents dependent on fishing mode. Mean living expenditures were lower for nonresidents who fished off private boats than for those who fished from shore or from charter boats, due in part to the fact that the primary trip purpose for many such respondents was to visit friends and family. Mean per-trip fishing expenditures ranged between $\$ 2.14$ (shore) and \$137.06 (charter) for local residents. Mean non-local Alaskan sportfishing expenditures varied from $\$ 4.50$ (shoreline) to $\$ 129.25$ (charter). On average, nonresidents spent $\$ 30.57$ to \$190.34 per shore and charter trip, respectively. Detailed information on average daily sportfishing expenditures by category is reported in Herrmann et al. (2000).

Estimates of 1997 saltwater angling effort in Lower and Central Cook Inlet were obtained from the Alaska Department of Fish and Game annual sport fish statewide harvest survey (ADF\&G 1998). Total sportfishing effort was multiplied by the average daily expenditures, disaggregated into time spent on the Kenai and time spent elsewhere in Alaska, and adjusted to reflect trip purpose. The majority (63.5\%) of respondents identified fishing for halibut or salmon in Cook Inlet as the primary purpose of their most recent trip. This response was most pronounced for non-local Alaskans, $87.9 \%$ of who listed fishing for halibut or salmon in Cook Inlet as the main reason for their trip. Less than half of the nonresidents (43\%) identified fishing for halibut or salmon in Cook Inlet as their primary motive. Another important reason (24.4\%) for nonresident trips was simply to visit and vacation in Alaska. Freshwater fishing and visiting relatives were also important motives for nonresidents (Herrmann et al 2000). While the empirical model 
can be used to estimate the probability that the average angler will take a specified trip, it does not explicitly account for how the probability that a particular angler would take that trip is affected by differences in the primary purpose of that individual's visit to the Kenai Peninsula. To account for these differences, we assumed that individuals who expressed saltwater fishing as the main purpose of their trip would forego their visit to the Kenai entirely if expectations of adverse angling conditions discouraged them from fishing at all. Individuals whose primary trip purpose was to visit friends or relatives, conduct business, or to take a cruise ship voyage or hunting trip were assumed to substitute other activities on the Kenai Peninsula if halibut and salmon saltwater sportfishing conditions were unattractive or unavailable. These assumptions were applied as a downward adjustment to the number of angler days in order to estimate total expenditures that were uniquely attributable to the salmon and halibut sportfishing opportunities in Lower and Central Cook Inlet. The total expenditures in Table 1 can be regarded as a measure of the economic significance, in terms of output in 1997 dollars, of the Cook Inlet marine sport fisheries for halibut and salmon. For purposes of generating economic impacts to the western Kenai Peninsula, we begin with a 1997 baseline of $\$ 28.5$ million. Increased or diminished angler spending will depend on changes in demand for recreational fishing, which is in part, a function of the expected trip attributes. This relationship is explored next.

\section{Participation-Rate Model}

Changes in expected catch or the expected size of fish caught (changes in trip attributes) affect the average sport fisher's decision to participate in (take) a sportfishing trip, regardless of whether the attribute change is due to natural population fluctuations, regulatory change, or environmental damage. That is, changes in fishery regulations, environmental quality, resource abundance, or trip costs, affect participation decisions. In contrast to previous studies (e.g., Holland and Ditton 1992, Aas 1995, Thunberg et al. 1999) that model population-level changes in the demand for recreational fishing based on exogenous demographic characteristics, we modeled the individual participation decision as a binary 
dependent variable explained by price, demographic characteristics, and angler success expressed in terms of the composition, magnitude, and average size of fish caught. The model can be expressed as:

$$
y_{i t}^{*}=\beta_{0}+\beta_{1} p_{i t}+f_{l}\left(n_{i t s} \bar{x}_{i t s}\right)+f_{2}\left(n_{i t s}\right)+f_{3}\left(z_{i l}\right)
$$

The dependent variable $y_{i t}^{*}$ takes on the value of $1(0)$ if individual $i$ with demographic characteristics $z_{i l}$ would (would not) have taken trip $t$ with price $p_{i t}$ and trip attributes $n_{i t s}$ and $\bar{x}_{i t s}$. Where the $z_{i l}$ are realizations of categorical variables representing per-capita household income, gender, age, and education for individual $i, p_{i t}$ is the price paid by individual $i$ for trip $t, n_{i t s}$ is the number of fish of species $s$ (halibut, chinook, coho) caught by individual $i$ on trip $t$, and $\bar{x}_{i t s}$ is the average weight of fish of species $s$ caught by individual $i$ on trip $t$. The functions $f_{1}(\bullet)$ and $f_{2}(\bullet)$ were specified as simple second order polynomials. Specifically, $f_{I}(\bullet)$ includes linear and quadratic terms and cross-products for all three species and $f_{2}(\bullet)$ includes linear and quadratic terms in the number of halibut caught. This specification allows for non-constant marginal utility of catch and substitution/complementarity effects across species. The function $f_{3}(\bullet)$ was specified as linear and additively separable in all variables.

Survey respondents were presented with trips described by a combination of: one of three costs levels (\$100, \$170, \$240 per day); one of four halibut catch (keep and release) levels $(0,2,4,6$ fish per trip); one of four average halibut weights $(0,20,40,80 \mathrm{lbs}$ per fish); one of three chinook catch levels $(0,1,2$ fish per trip); one of four average chinook weights $(0,15,25,50 \mathrm{lbs}$ per fish); one of four coho catch levels (0, 2, 4, 6 fish per trip); and one of two average coho weights (0, $7 \mathrm{lbs}$ per fish). Efficient specification of hypothetical trip attributes, and survey design and administration are described in Lee et al. (1999).

Equation (1) was estimated along with indicator variables to differentiate between Alaskans and nonresidents. Because the same general study design was presented to each group, only one random effect parameter, $\rho$, was estimated. Estimates of the 35 parameters and associated $t$-statistics are reported in Table 2. Twenty-six of the parameters are significantly greater (less) than zero at the $5 \%$ level and the 
point estimates of the parameters and their signs accord well with economic theory: the price coefficients are significantly less than zero; the coefficients on halibut, chinook, and coho weights and halibut catches are significantly greater than zero; the weight and catch squared terms are all negative, implying that anglers experience decreasing marginal utility; and, the cross-products of the weights of halibut, chinook, and coho are significantly less than zero, suggesting that catches of each species are substitutes for catches of the others. The presence of an identifiable random effect is supported by the statistical significance of the estimated parameter. With the exception of gender in the Alaskan equation and education in the nonresident equation, the demographic characteristics were not statistically significant.

Model forecasts are based on the sample enumeration method (BenAkiva and Lerman 1987), which takes into account differences in socioeconomic characteristics and variability in the number of days fished per year by developing forecasts for each individual in the sample. This information is used to weight the simulations by the number of days fished:

$$
\% \Delta \text { Participation }_{\alpha}=\frac{\sum_{i}\left[\Phi\left(\hat{u}_{i, 1}\right) \text { days }_{i}\right]-\sum_{i}\left[\Phi\left(\hat{u}_{i, 0}\right) \text { days }_{i}\right]}{\sum_{i}\left[\Phi\left(\hat{u}_{i, 0}\right) \text { days }_{i}\right]} .
$$

Where $\hat{u}_{i, j}$ is the forecast of indirect utility for individual $i$ taking a fishing trip characterized by attributes $j, j=0$ denotes the initial or starting point fishing trip attributes and $j=1$ denotes the new fishing trip attribute levels based on an $\alpha$ percent change from the $j=0$ levels, $\% \Delta$ means percentage change, $\Phi(\bullet)$ is the cumulative normal distribution function, and days $s_{i}$ is the number of days individual

$i$ fished in marine waters off the Kenai Peninsula in 1997. Confidence intervals around the separate estimates for Alaskan resident and nonresident participation-rate levels were generated following Krinsky and Robb (1986).

\section{Input-Output Model}

Input-output models have been widely used to evaluate the regional impacts of development projects and regulatory policy changes. Examples include assessments of the impacts of changes in National Forest 
harvest policies (Summers and Birss 1991), federal grazing policies (Geier and Holland 1991), community development strategies (Geier et al. 1994), and regulatory changes in management of commercial crab fisheries off Alaska (Natcher 1996) and guided sport fisheries off New England (Steinback 1999).

We selected IMPLAN (Olson and Lindall 1997) as a base for our model. IMPLAN includes a representation of 21 economic and demographic variables for each of 528 industrial sectors. We obtained zip-code area level IMPLAN data sets; the smallest geographical resolution available for coverage of the western Kenai Peninsula. In regions such as Alaska, with small numbers of firms (frequent disclosure problems), and a rapidly evolving and heavily resource dependent economy, it is particularly essential that the transaction coefficients be groundtruthed to the greatest extent practicable. Consequently, team members spent two weeks in the study region meeting with individuals, business owners, industry representatives, and local government officials for purposes of improving the original database. Only 138 of IMPLAN's 528 sectors are present in the western Kenai Peninsula. Corrections to the output and value added components for each IMPLAN sector for each zip code area are detailed in Herrmann et al. (2000).

Because recreational fishing is not explicitly represented in IMPLAN, we developed a programming module to disaggregate IMPLAN sectors that include recreation-based activities to highlight activities generated by recreational fishing. This module utilizes IMPLAN generated response coefficients and secondary regional economic data as inputs in model formulation. The secondary model data is augmented with data for the target sectors (e.g., sport/charter industry) supplied from primary and secondary sources as well as discussions with industry representatives. Thus this module, through its input-output framework, explicitly accounts for linkages between various economic sectors, according to production and consumption patterns. Individual sportfishing activities are accounted for by expenditure patterns in retail and service sectors rather than treated as direct income generating activities such as guiding, harvesting, and processing. The recreational fishing module allocates recreational expenditures among these sectors. The sportfishing expenditure data were obtained from response to the angler survey 
described above. The operating cost data required for modeling charter operations were derived through discussions with charter operators and industry representatives.

In contrast to manufacturing sectors, which are well represented in IMPLAN, retail sectors are highly aggregated. Because impacts associated with changes in sportfishing related expenditures are transacted primarily at the retail level, tracking them requires disaggregation of some of the IMPLAN sectors. While aggregating two or more IMPLAN sectors is straightforward, there are many consistent ways to disaggregate sectors. For example, while charter trip payments are included in IMPLAN's Amusement and Recreation Services sector, without information describing the intermediate demand components associated with charters, it is not possible to know how to correctly adjust the vector of technical coefficients. Although it might be tempting to represent the new "Charter" sector with a vector of technical coefficients generated as a simple fraction of the Amusement and Recreation sector, doing so would render the technical coefficients matrix singular and preclude model solution.

Bushnell and Hyle (1985), Wolsky (1984), and Gillen and Guccione (1990) suggest approaches that directly modify the technical coefficients matrix. Jensen (1997) and Steinback (1999) note instead that running an impact scenario in IMPLAN that mirrors that sector's purchases can simulate the intermediate demand effects of the aggregated sector. Although the former approach is technically preferable, it requires a reprogramming of IMPLAN's social accounting matrices to reflect the characteristics of the disaggregated subsector. By including the new sector within the model, the changes are noted within the use (absorption), byproducts, and final demand matrices. Regional purchase coefficients and value-added features are similarly constructed for the new sector. The impact scenario option is much less tedious. Using IMPLAN's front end, a demand shock is executed with components (events) that mirror the proportions of the simulated sector's production function. The resulting impacts can then be used to calculate response coefficients (normal multipliers). However, because the new subsector is not explicitly defined in the IMPLAN model, there is no opportunity for it to play a role in the intermediate demand of other sectors within the model, thus leading to possible underestimation of the actual multiplier effect. We 
used the first approach to represent charter operations and the second to model the impacts of angler expenditures.

A model of the average charter operation's expenditure patterns was constructed using data reported in NPFMC $(1997,2000)$ as well as discussions with local experts and members of industry. Standard Industrial Classification (SIC) codes for the corresponding inputs were translated to the IMPLAN sectoral scheme and a production function was estimated for the 1997 charter sector sales value of $\$ 13.6$ million, based on average per day charter fees and Alaska Department of Fish and Game estimates of charter client days (see Herrmann et al. 2000).

The SIC based coefficients were aggregated according to their corresponding IMPLAN sectors to provide an estimate of the average production function for the marine charter sector and are reported in Table 3. These technical coefficients were applied to the baseline charter sales data presented in Table 4 (For a more detailed accounting of the individual expense categories, corresponding SIC codes and translation to the IMPLAN sectoral scheme, see Herrmann et al. 2000). Impact scenarios were run in IMPLAN to generate response coefficients for all other expenditure categories. These response coefficients and those developed for the charter operation sector were then integrated into the stand-alone recreational module (Herrmann et al. 2000). Where data limitations prevented construction of original production functions, the model defaults to the values reported for input coefficients in Jensen (1997).

To be useful, impact models should be linked to a demand model for the activity in question. Although an accurately groundtruthed input-output model may correctly predict the regional impact of a given change in the number of sportfishing trips taken, that capability is of limited value in the absence of a companion model for predicting how the number of sportfishing trips varies as a function of observable or controllable trip attributes. That is, for an impact model to serve as a tool for evaluating the effects of management actions, fluctuations in resource abundance, or environmental damages, it is essential to know how those attributes affect participation rates. The relevancy of our impact simulations arises from the empirically (behaviorally) based model of participation decisions. 


\section{Simulations and Software}

The simulation model uses the participation rate model, baseline expenditure estimates, and IMPLAN generated response coefficients to estimate the economic impacts of changes in angler spending to the western Kenai Peninsula. The impacts are expressed in terms of output (sales), income, employment, and other value added variables. Altered spending behavior is driven by changes in participation, which are determined by changes in trip attributes (e.g., fish catch and size, and trip cost). We apply the resulting percentage changes in effort, by residency and fishing mode, on a one-to-one basis to baseline angler-day expenditures that are directly attributable to sportfishing.

The simulations begin with the probability that the average angler will take a sportfishing trip, given a set of trip attributes. Regional economic impacts are measured in relation to baseline of expenditures and vary as sport fishers respond to changes in fishing trip attributes. Each of the nine categories of sport fishers (local, non-local Alaskans, and nonresidents $\times$ charter, private, and shore) is represented by a distinct expenditure pattern in the integrated model. We begin by using the total spending on the western Kenai, $\$ 28,524,174$ reported in Table 1 . This value can be regarded as a measure of the economic significance of the marine sport fishery in terms of sales, or output. However, this value includes spending by local residents. Because we assume that local residents freely substitute between sportfishing and other regional recreational activities, their expenditures need to be netted out. Subtracting the spending of Kenai Peninsula Borough residents from the total expenditures attributable to the Lower and Central Cook Inlet sport fisheries leaves $\$ 24,972,830$ of “new" money, money spent by non-local Alaskans and nonresidents. Fishing related and other expenditures amount to $\$ 15,263,165$ and $\$ 9,709,665$, respectively.

Increases in the amount of new money spent locally stimulate economic activity whereas decreased spending by non-locals leads to a reduction in economic activity. Variations in spending by non-locals are driven by the changes in effort predicted by the participation rate model. For every percentage change in effort measured by reduced or increased sportfishing-days, there is a proportional change in daily 
expenditures across each of the residency and sportfishing mode categories. The changed expenditures are summed and multiplied by the response coefficients to generate estimates of the economic impact of regulatory or environmentally induced changes in fishing trip attributes. The impacts are calculated in terms of output, employment, employee earnings, proprietors' income, personal income, other income, indirect taxes, and value added for direct, indirect, and induced effects.

Figure 1 depicts the response of resident and nonresident demand for sportfishing to changes in expected catch levels. The associated regional impacts are reported in Table 5 and represented in Figures 2-5. For example, a $10 \%$ reduction in expected catch results in an $8 \%$ decrease in overall effort; the weighted average of a $9.3 \%$ decrease in resident effort and a $5.8 \%$ decrease in nonresident effort. The reduction in resident and nonresident trips results in a $\$ 1.7$ million decrease in 'new' money spent, and lead to direct, indirect, and induced impacts of $-\$ 2.5$ million in output, $-\$ 1.0$ million in personal expenditures, and a net loss of 72 jobs. Note that the impact is nonlinear and that the marginal impact declines as catch increases. That is, there is a larger decline in expenditures and jobs when moving from a $20 \%$ decrease to a $30 \%$ decrease in expected catch than when moving from a $20 \%$ increase to a $10 \%$ increase. This result is consistent with the principle of declining marginal utility where utility, and therefore participation, increases at a decreasing rate with incremental changes in angler success.

The software module used to calculate changes in economic activity from hypothetical changes in expected trip attributes is described in Hamel et al. (2000). The model allows users to simulate changes in expected fish catch, size, and trip costs and to isolate these effects to the economic activities of specified fishery modes (charter, private, shore). Although the module was groundtruthed to 1997 values, it can be applied to more recent periods by incorporating updated effort data and using an inflation index. For example, in 1999 when the total fishing days on the lower Cook Inlet was 185,114 angler days, it is estimated that nominal expenditures of $\$ 23,485,259$ was spent in the region by non-local Alaskans and nonresidents ( $\$ 14,124,718$ of fishing related expenses and $\$ 9,360,541$ of other expenses). However, these dollar estimates still hinge on 1997 survey data for individual expenses and as would all future estimates 
until a new survey is undertaken. Because the 1999 estimated expenditures are slightly lower than in 1997, and the resulting effects of changes in expected catches would be slightly less.

\section{Conclusions}

The regional economic impact of recreational activities depends on the number of participants and their expenditure patterns. Variations in the number of participants arise from changes in the demand for recreational activity and are, in part, due to alterations in expected trip attributes. Consequently, modifications of trip attributes alter the probability that the mean recreationist will take a given trip, change the expected number of participants, and affect regional economic activity. The advantage of formally linking a behaviorally based model of the demand for recreation with a regional economic model is that so doing allows a direct evaluation of the economic impact of predictable or controllable changes in trip attributes.

This approach is demonstrated in an application to the Lower and Central Cook Inlet saltwater sport fisheries for Pacific halibut and salmon. In the application, an econometric model of the determinants of individual participation decisions is linked to a simulation procedure to aggregate across individual decisions and estimate total sportfishing effort, and a regional input-output model that describes primary and secondary expenditure patterns. Altered spending behavior is driven by changes in participation, which are determined by changes in trip attributes (e.g., fish catch and size, and trip cost). The expenditures are summed and multiplied by the response coefficients to generate estimates of the economic impact of regulatory or environmentally induced changes in fishing trip attributes. The participation model is stochastic and allows for non-constant marginal utility; consequently primary and secondary impacts exhibit nonlinear responses to variations in trip attributes. In addition to being consistent with the theory of declining marginal utility, the nonlinear response of participation to changes in catch has practical relevance: a linear model would over-predict the increase in angler effort associated with an increase in catch or fish size and under-predict the reduction in angler effort that would result from a decrease in catch or fish size. Moreover, because the model is stochastic, confidence bounds can 
be estimated for changes in participation rates and associated changes in regional expenditures. The software module used to calculate changes in economic activity (Hamel et al. 2000) allows users to simulate changes in expected fish catch, size, and trip costs and to isolate these effects to the economic activities of specified fishery modes (charter, private, shore).

A baseline, reflecting the 1997 mean trip, is reported along with five sample levels of changes in expected catch rates. Such variations in catch could result from natural fluctuations in abundance, changes in allocation between commercial, subsistence, and sport fishers, changes in bag and possession limits, or environmental damage resulting from, for example, minerals exploration, development, production, or transportation activities.

In any large-scale economic study, there is a tradeoff between economic realism and cost in terms of money and time. This analysis is one of the most complex attempted for valuation of a sport fishery. However, every study is limited by explicit and implicit economic assumptions and data limitations. In this study, where there was plenty of theoretical work but very little precedence for applied analysis, much of the applied work was new territory. Looking back over the project some things worked out very well and others could have been improved. For the future, one area that needs further addressing is that in the participation model, when estimating the changes in the probability that individual fishers would take a trip, given varying trip attributes, it is assumed that the price of the trip will remain constant. In other words, we assume that supply was perfectly elastic. While this assumption is reasonable for shore and private trips, it is probably incorrect for charter trips. To the extent that charter trips make up a sizeable portion of sportfishing effort, and to the extent that charter trips do not exhibit perfectly elastic supply curves, there may be price adjustment especially in the short-run. For example, charter operators might respond to a short-run change in expected catches by lowering their prices and keeping their customer base rather than holding prices constant and losing customers as assumed by in our model. While our assumption is valid in the long run, it may be less accurate in the short run. 


\section{References}

Aas O (1995) Constraints on sportfishing and effect of management actions to increase participation rates in fishing. North American Journal of Fisheries Management 15: 631-638.

Alaska Department of Fish and Game (ADF\&G) (1998) Harvest, catch, and participation in Alaska Sport fisheries during 1997. Alaska Department of Fish and Game, Division of Sport Fisheries, 333 Raspberry Road, Anchorage, AK, Fishery Data Series No. 9825.

BenAkiva M, Lerman SR (1985) Discrete choice analysis: theory and applications to travel demand. MIT Press, Cambridge, MA.

Bushnell RC, Hyle M (1985) Computerized models for assessing the economic impact of recreation and tourism. In: Probst DB (ed) Assessing the economic impacts of recreation and tourism. Southeastern Forest Experiment Station, Asheville, SC.

Cohen MJ (1993) Economic aspects of technology accidents: an evaluation of the Exxon Valdez oil spill on Southcentral Alaska. Ph.D. dissertation, University of Pennsylvania.

Coughenower DD (1986) Homer, Alaska guided sport fishing industry study. Marine Advisory Bulletin No. 22, Alaska Sea Grant College Program, University of Alaska, Fairbanks AK.

Criddle KR (1994) Economics of resource use: a bioeconomic analysis of the Pacific halibut fishery. In: Proceedings of the Fourth International Symposium of The Conference of Asian and Pan-Pacific University Presidents, Alaska Sea Grant, Anchorage AK.

Crutchfield JA, Zellner A (1962) Economic aspects of the Pacific halibut fishery. Fishery Industrial Research 1: 1-173.

Geier H, Holland D (1991) Economic aspects of federal livestock grazing policy: a regional economic analysis for the Okanogan-Ferry Area in Washington. Department of Agricultural Economics Staff Paper AE913, Washington State University, Pullman, WA.

Geier H, Holland D, Schuster E (1994) Using IMPLAN to analyze small county economies for identification of development opportunities. United States Department of Agriculture, Forest Service Intermountain Research Station.

Gillen WJ, Guccione A (1990) Disaggregating input-output models; an alternative to Wolsky's method. Economic Systems Research 2: 39-42.

Hamel C, Herrmann M, Lee ST, Criddle KR (2000) An economic assessment of Lower Cook Inlet sport fisheries: software program and manual. University of Alaska Fairbanks Coastal Marine Institute, Fairbanks, AK.

Herrick Jr SF, Strand I, Squires D, Miller M, Lipton D, Walden J, Freese S (1994) Application of costbenefit analysis to fisheries allocation decisions: the case of Alaska walleye pollock and Pacific cod. North American Journal of Fisheries Management 14: 726-741. 
Herrmann M (1993) Using an international econometric model to forecast Alaska salmon revenues. Marine Resource Economics 8: 249-271.

Herrmann M (1994) The Alaska salmon fishery: an industry in economic turmoil. Journal of Aquatic Food Product Technology 3: 5-22.

Herrmann M (1996) Estimating the induced price increase for Canadian Pacific halibut with the introduction of the individual vessel quota program. Canadian Journal of Agricultural Economics 44: 151-164.

Herrmann M (2000) The individual vessel quota price induced effects for Canadian Pacific halibut: before and after Alaska IFQs. Canadian Journal of Agricultural Economics (in press).

Herrmann M, Greenberg JA (1994) A revenue analysis of the Alaska pink salmon fishery. North American Journal of Fisheries Management 14: 537-549.

Herrmann M, Lee ST, Hamel C, Criddle KR, Geier HT, Greenberg JA, Lewis CE (2000.) An economic assessment of the sport fisheries for halibut, chinook and coho salmon in Lower Cook Inlet: final report. University of Alaska Fairbanks Coastal Marine Institute, Fairbanks, AK.

Holland SM, Ditton RB (1992) Fishing trip satisfaction: a typology of anglers. North American Journal of Fisheries Management 12: 28-33.

Homans FR (1993) Modeling regulated open access resource use. Doctoral dissertation, University of California, Davis, CA.

Jensen Consulting. 1997. North Pacific Fishery Management Council recreational economic impact model. Reference manual for version 3.0.

Jones and Stokes Associates Inc (1987) Southcentral sport fishing economic study. Alaska Department of Fish and Game, Division of Sport Fisheries, 333 Raspberry Road, Anchorage, AK.

Krinsky I, Robb AL (1986) On approximating the statistical properties of elasticities. Review of Economics and Statistics 9: 715-719.

Lee ST, Herrmann M, Wedin I, Criddle KR, Hamel C, Greenberg JA (1999) Summary of angler survey: saltwater sportfishing off the Kenai Peninsula, Alaska: final report, Alaska Sea Grant Project 98403 R1417. University of Alaska, Fairbanks, AK.

Lin B-H, Richards HS, Terry JM (1988) An analysis of the exvessel demand for Pacific halibut. Marine Resource Economics 4: 305-314.

Minerals Management Service (MMS) (1995) Final environmental impact statement for Cook Inlet planning area oil and gas lease sale 149. OCS/EIS/EA 95-0066, U.S. Minerals Management Service, Anchorage, AK.

Natcher WC (1996) Economic Evaluation of superexclusive designation for the summer Norton Sound red king crab fishery. Masters Thesis, University of Alaska, Fairbanks, AK. 
National Research Council (NRC) Committee to Review Individual Fishing Quotas (1999) Sharing the fish: toward a national policy on individual fishing quotas. National Research Council, National Academy Press.

North Pacific Fishery Management Council (NPFMC) (1991) Revised supplement to the draft supplemental environmental impact statement and regulatory impact review/initial regulatory flexibility analysis to the groundfish fishery management plans for the Gulf of Alaska and the Bering Sea/Aleutian Islands: longline and pot gear sablefish management in the Gulf of Alaska and the Bering Sea/Aleutian Islands. North Pacific Fishery Management Council, Anchorage, AK.

North Pacific Fishery Management Council (NPFMC) (1997) Draft environmental assessment/regulatory impact review/initial regulatory flexibility analysis for proposed regulatory amendments to implement management alternatives for the guided sport fishery for halibut off Alaska, North Pacific Fishery Management Council, Anchorage, AK.

North Pacific Fishery Management Council (NPFMC) 2000 Draft environmental assessment/regulatory impact review/initial regulatory flexibility analysis for a regulatory amendment to implement management measures under a guideline harvest level and/or moratorium for halibut in areas $2 \mathrm{C}$ and 3A. North Pacific Fishery Management Council, Anchorage, AK.

Northern Economics (1990) Economic impacts of the S.S. Glacier Bay oil spill. U.S. Minerals Management Service, Alaska Outer Continental Shelf Region, Anchorage, AK.

Olson D, Lindall S (1997) IMPLAN professional software, analysis, and data guide. Minnesota IMPLAN Group, Stillwater, MN.

Steinback SR (1999) Regional economic impact assessments of recreational fisheries: an application of the IMPLAN modeling system to marine party and charter boat fishing in Maine. North American Journal of Fisheries Management 19: 725-736.

Summers P, Birss H (1991) Revitalizing the timber dependent regions of Washington: Report for the Washington Department of Trade and Economic Development.. Northwest Policy Center, University of Washington Graduate School of Public Affairs, Seattle, WA.

Thunberg E, Steinback SR, Gray G, Gautam A, Osborn M (1999) Summary report of methods and descriptive statistics for the 1994 Northeast Region marine recreational fishing participation survey, NOAA Technical Memorandum NMFSF/SPO39.

Wolsky AM (1984) Disaggregating input-output models. The Review of Economics and Statistics 66: 283-291. 
Table 1. Total 1997 expenditures (\$million) attributable to Lower and Central Cook Inlet saltwater sportfishing adjusted to reflect trip purpose ${ }^{1}$

\begin{tabular}{lccc}
\hline & $\begin{array}{c}\text { Spending on Kenai } \\
\text { Peninsula }\end{array}$ & $\begin{array}{c}\text { Spending Elsewhere in } \\
\text { Alaska }\end{array}$ & Total Spending \\
\hline Fishing Expenditures & & - & $\$ 10.366$ \\
Charter fees & $\$ 10.366$ & $\$ 1.978$ \\
Gear & $\$ 1.904$ & $\$ 2.307$ & $\$ 0.269$ \\
Processing fees & $\$ 2.307$ & - & $\$ 2.024$ \\
Derby fees & $\$ 0.269$ & $\$ 0.671$ \\
Boat fuel \& repairs & $\$ 1.732$ & $\$ 0.291$ & $\$ 17.617$ \\
Moorage or haul fees & $\$ 0.671$ & - & \\
Total Fishing Expenditures & $\$ 17.251$ & & \\
Ancillary Expenditures & & $\$ 0.366$ & $\$ 3.071$ \\
Auto and truck fuel & & $\$ 2.452$ & $\$ 2.697$ \\
RV rentals & $\$ 2.619$ & $\$ 1.015$ & $\$ 3.242$ \\
Lodging & - & $\$ 0.516$ & $\$ 3.051$ \\
Groceries & $\$ 3.226$ & $\$ 0.488$ & $\$ 16.443$ \\
Restaurant \& Bar & $\$ 2.864$ & $\$ 5.170$ & 34.061 \\
\hline
\end{tabular}

${ }^{\top}$ From Herrmann et al (2000) Table 24.

Table 2. Participation model parameter estimates. ${ }^{1}$

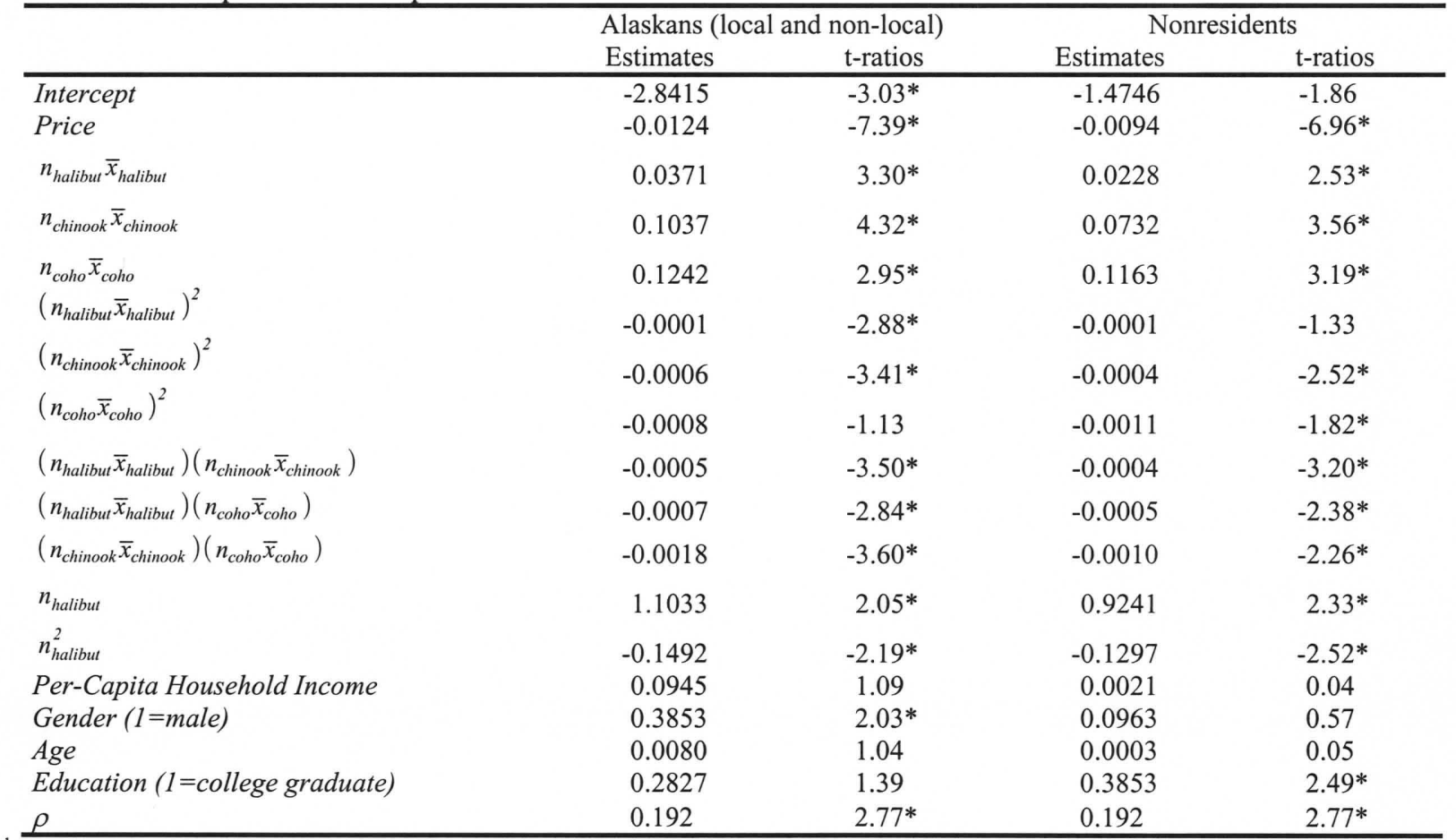

${ }^{1}$ From Herrmann et al (2000) Table 28.

* Significantly greater (less) than zero at $p \leq 0.05$. 
Table 3. Parameters values for the estimated average production function for the marine charter sector

\begin{tabular}{llllll}
\hline \multicolumn{1}{c}{ Expense Category } & Coefficient & \multicolumn{1}{c}{ Expense Category } & Coefficient & Value Added Category & Coefficient \\
\hline Advertising & 0.0410 & Medical & 0.0015 & Employee Comp & 0.1147 \\
Bait & 0.0133 & Office Supplies & 0.0135 & Proprietor Income & 0.1949 \\
Computer Total & 0.0066 & Professional Services & 0.0098 & OPTI & 0.0339 \\
Contract Services & 0.0035 & Repair/Maint/Tools/Supplies & 0.0130 & Indirect Bus Tax (Sales Tax) & 0.0306 \\
Dues & 0.0139 & Subscriptions & 0.0018 & & \\
Electronic Supplies & 0.0004 & Total Boat Maintenance & 0.0132 & \\
Entertainment & 0.0009 & Total Borough Tax & 0.0369 & \\
Fed Income Tax & 0.0416 & Total Insurance & 0.0392 & \\
Fuel \& Lubrication & 0.1356 & Total Licenses & 0.0243 & & \\
Gear Replacement & 0.0216 & Total Travel & 0.0181 & \\
Groceries & 0.0008 & Total Truck Exp & 0.0178 & \\
Hull Repair & 0.0054 & Total Utilities & 0.0380 & \\
Interest Paid (Boat) & 0.0542 & Trade Shows & 0.0214 & \\
Moorage \& Boat Storage & 0.0182 & Work Gear/Client Supplies & 0.0202 & & \\
\hline Absorption Coefficient & & & 0.6259 & Value Added Coefficient & 0.3741 \\
\hline
\end{tabular}

Table 4. Absorption sectors and coefficients for sportfishing expenditure categories

\begin{tabular}{lcll}
\hline \multicolumn{1}{c}{ Expenditure Category } & IMPLAN Sector \# & IMPLAN Sector Name & Coefficient \\
\hline Transportation, Food \& Lodging & 451 & Automotive dealers \& service stations & 1.00 \\
Auto or Truck Fuel & 450 & Food stores & 0.75 \\
Groceries & 455 & Miscellaneous retail & 0.25 \\
& 463 & Hotels and lodging places & 1.00 \\
Lodging & 454 & Eating \& drinking & 1.00 \\
Restaurant \& Bar & & & 0.10 \\
Fishing Expenditures & 393 & Boat building and repairing & 0.05 \\
Boat Fuel, Lubricants \& Repairs & 448 & Building materials \& gardening & 0.70 \\
& 451 & Automotive dealers \& service stations & 0.10 \\
& 455 & Miscellaneous retail & 0.05 \\
& 482 & Miscellaneous repair shops & Table 6 \\
Charter \& Guide Fees & & & 1.00 \\
Fish Processing or Packaging & 98 & Prepared fresh or frozen fish or seafood & 1.00 \\
Fishing Derby Entry Fees & 503 & Business associations & 0.15 \\
Fishing Gear & 98 & Prepared fresh or frozen fish or seafood & 0.05 \\
& 421 & Sporting and athletic goods, n.e.c. & 0.20 \\
& 449 & General merchandise stores & 0.50 \\
Haul Out \& Moorage Fees & 455 & Miscellaneous retail & 0.10 \\
& 435 & Motor freight transport and warehousing & 0.45 \\
& 436 & Water transportation & 0.10 \\
& 451 & Automotive dealers \& service stations & 0.15 \\
& 473 & Equipment rental and leasing & 0.20 \\
\hline
\end{tabular}

Table 5. Estimated regional economic impacts of changes in expected catch (\$)

\begin{tabular}{|c|c|c|c|c|c|}
\hline$\%$ Change in Catch & $\begin{array}{l}\% \text { Change in } \\
\text { Participation }\end{array}$ & $\begin{array}{c}\text { Change in Angler } \\
\text { Expenditures }\end{array}$ & $\begin{array}{c}\text { Change in Output } \\
(\$)\end{array}$ & $\begin{array}{c}\text { Change in Personal } \\
\text { Income (\$) }\end{array}$ & $\begin{array}{c}\text { Change in } \\
\text { Employment (Jobs) }\end{array}$ \\
\hline$-30 \%$ & $-31.3 \%$ & $-6,962,057$ & $-10,062,164$ & $-4,245,863$ & -292 \\
\hline$-20 \%$ & $-18.5 \%$ & $-4,026,681$ & $-5,819,726$ & $-2,456,990$ & -168 \\
\hline$-10 \%$ & $-8.0 \%$ & $-1,718,435$ & $-2,483,646$ & $-1,049,021$ & -72 \\
\hline $0 \%$ & $0.0 \%$ & 0 & 0 & 0 & 0 \\
\hline$+10 \%$ & $5.9 \%$ & $1,225,825$ & $1,771,687$ & 748,812 & 51 \\
\hline$+20 \%$ & $+10.0 \%$ & $2,068,612$ & $2,989,775$ & $1,263,986$ & 86 \\
\hline
\end{tabular}


Alaskan Residents

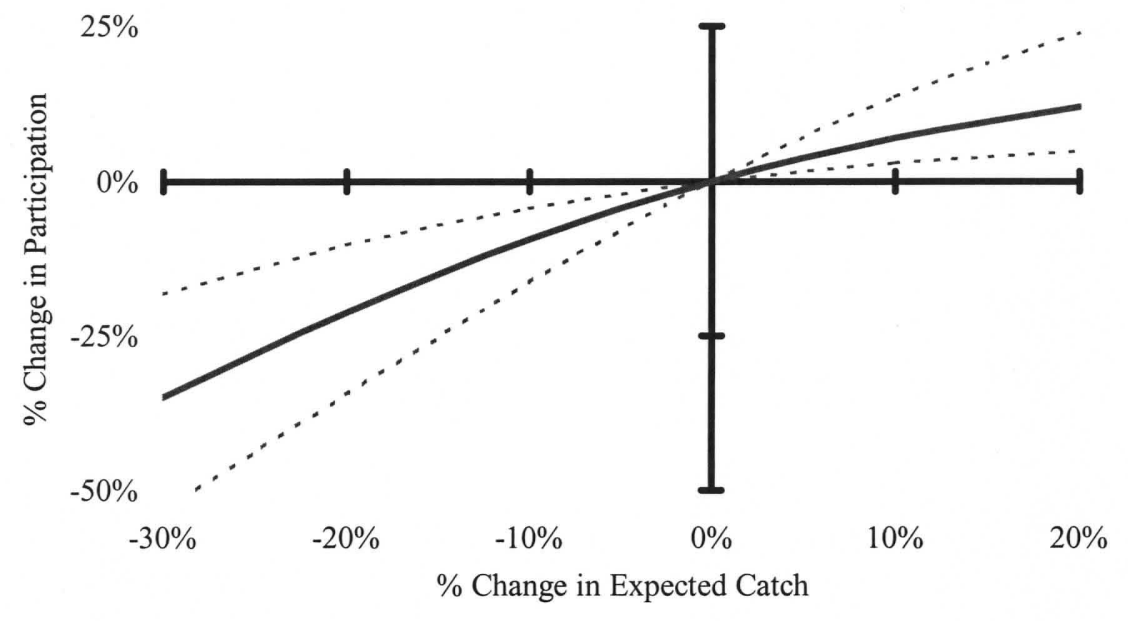

Nonresidents

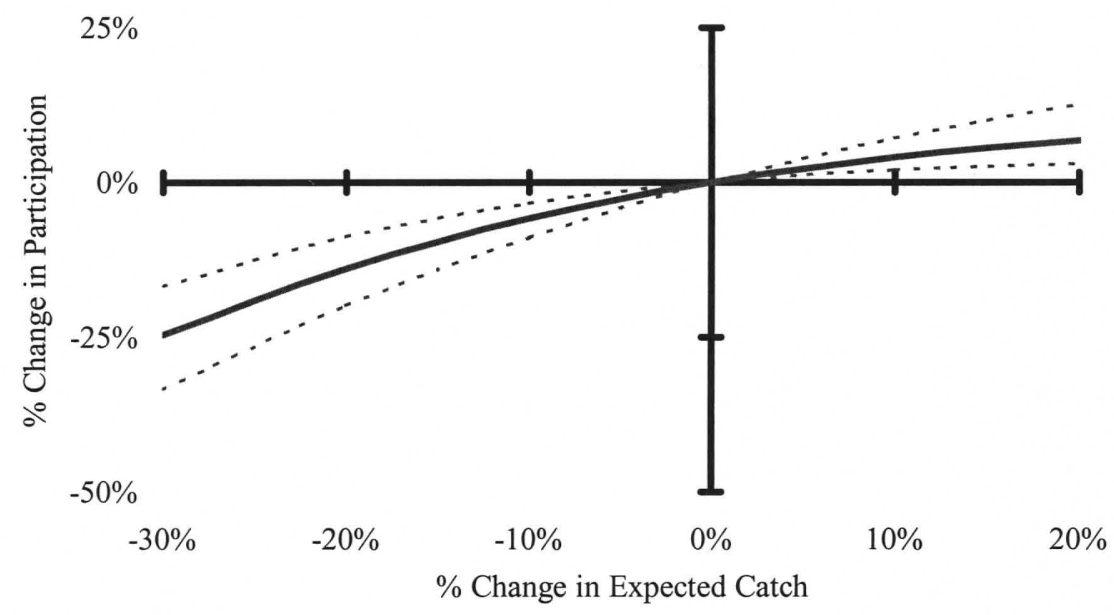

Fig. 1. Percentage changes in days fished by resident and nonresident anglers resulting from changes in the expected sportfishing catches. (90\% confidence intervals are represented with dotted lines.) 


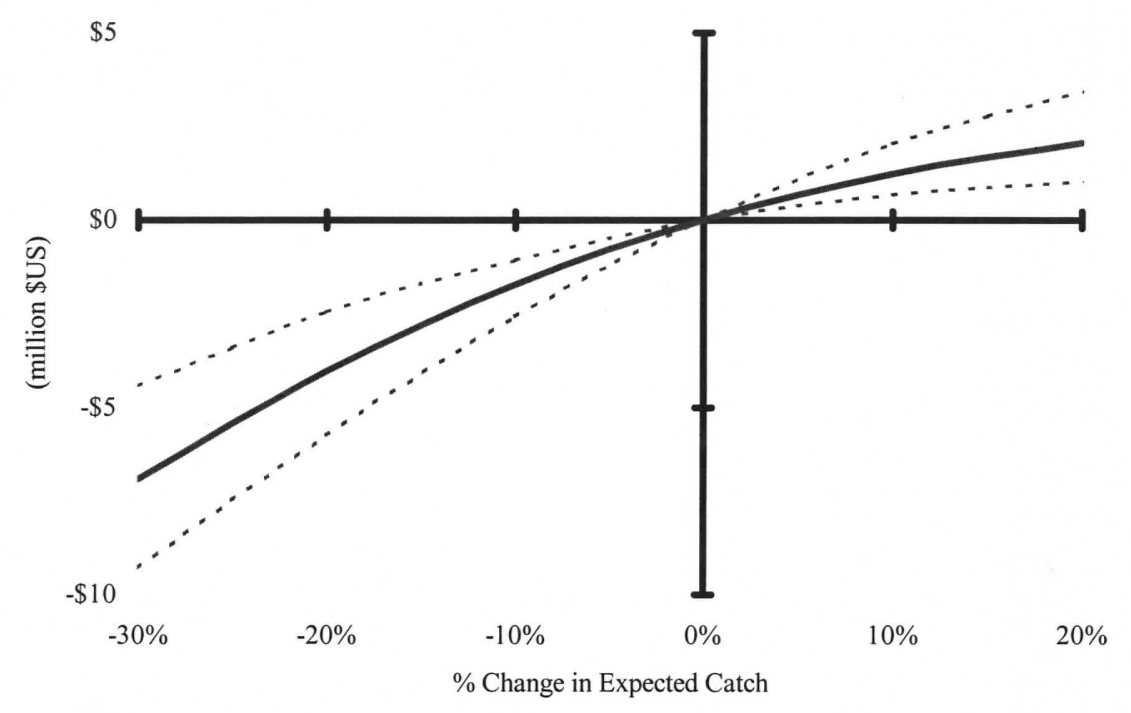

Fig. 2. Change in angler expenditures resulting from changes in the expected sportfishing catches. (90\% confidence intervals are represented with dotted lines.)

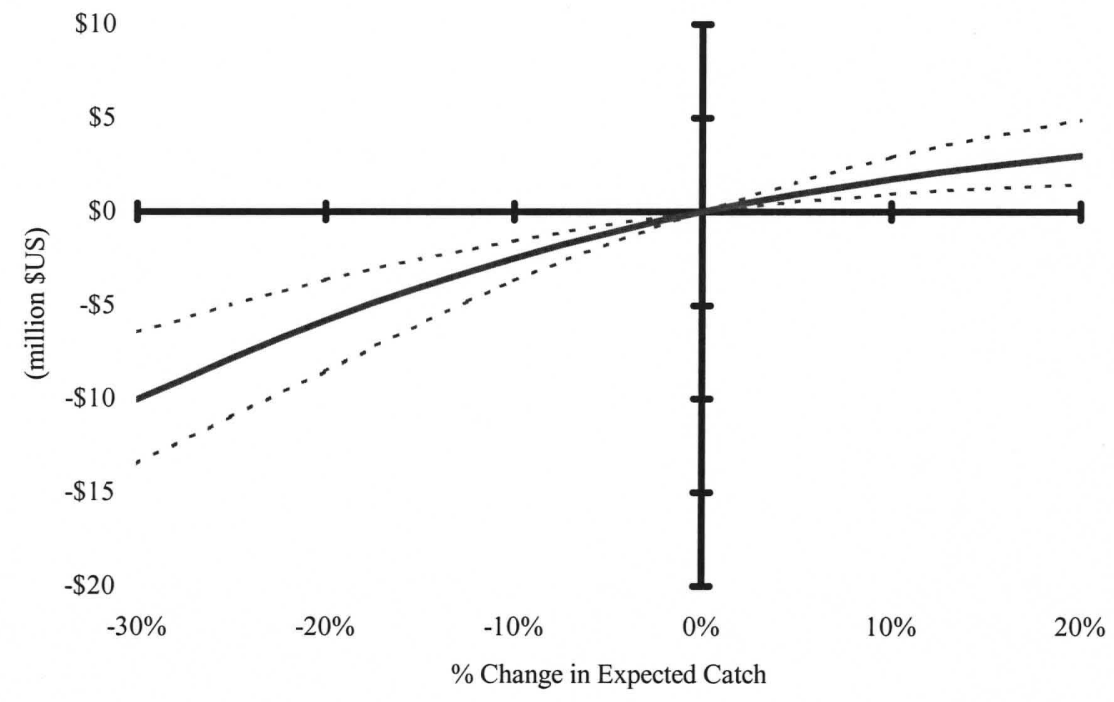

Fig. 3. Change in industry output resulting from changes in the expected sportfishing catches. $(90 \%$ confidence intervals are represented with dotted lines.) 


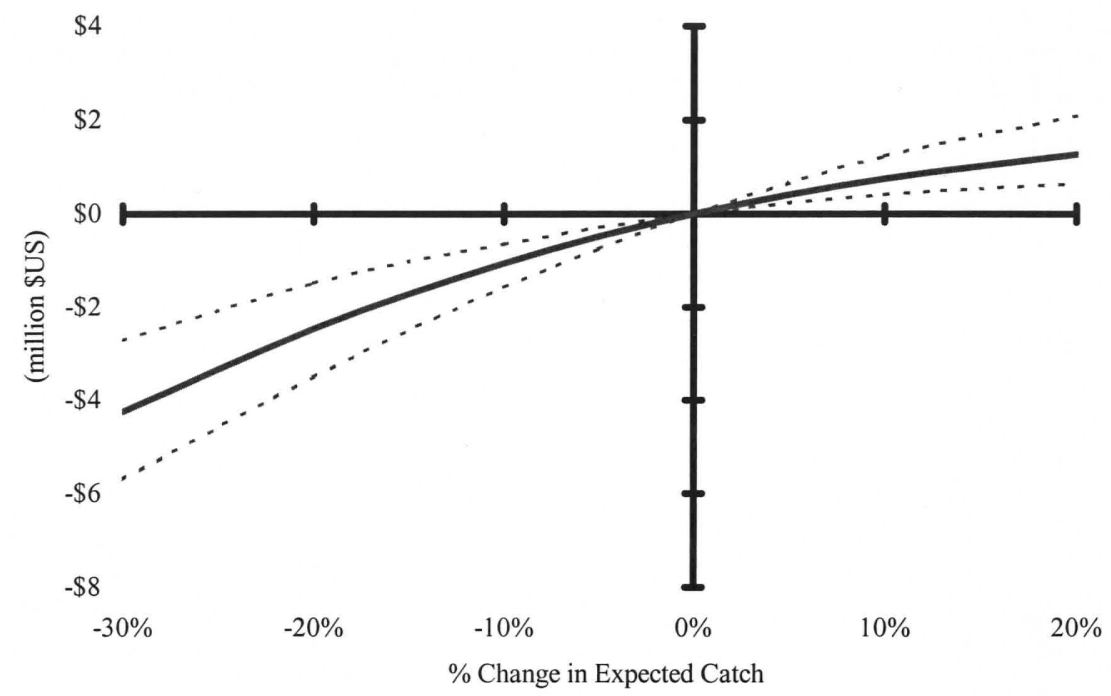

Fig. 4. Change in personal income resulting from changes in the expected sportfishing catches. (90\% confidence intervals are represented with dotted lines.)

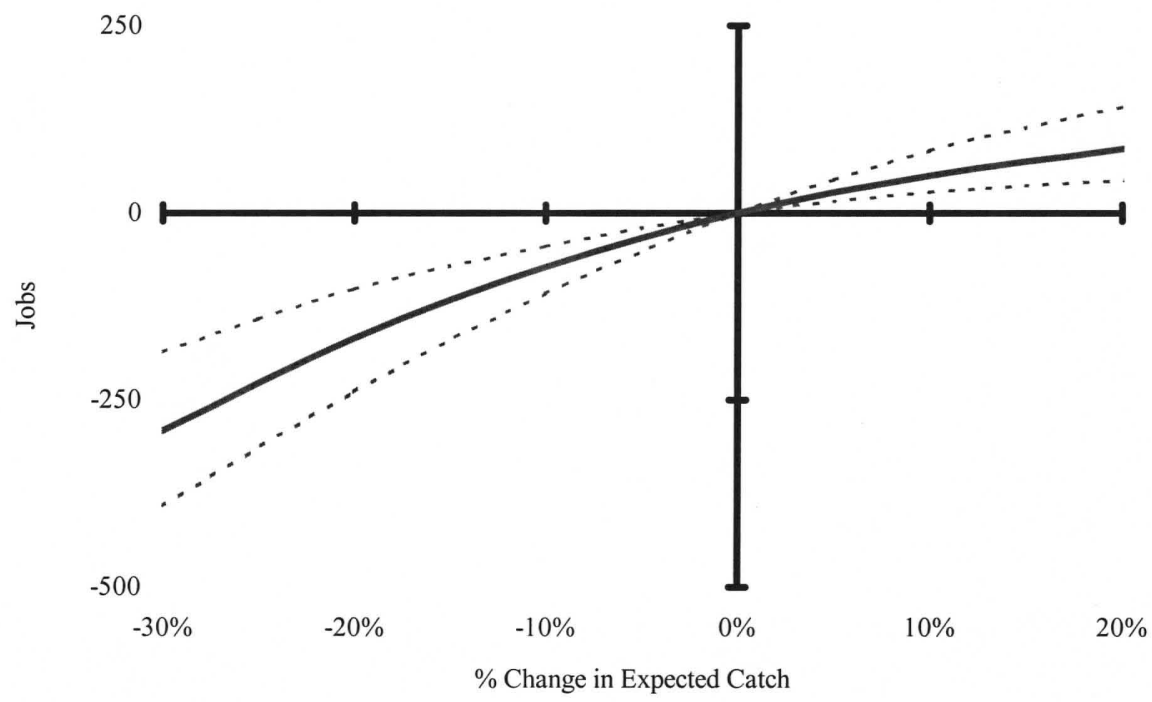

Fig. 5. Change in employment resulting from changes in the expected sportfishing catches. $(90 \%$ confidence intervals are represented with dotted lines.) 


\section{Linking sportfishing trip attributes, participation decisions, and regional economic impacts in Lower and Central Cook Inlet, Alaska}

\author{
Charles Hamel $^{1}$, Mark Herrmann ${ }^{2}$, S. Todd Lee ${ }^{3}$, Keith R. Criddle ${ }^{4}$, Hans T. Geier ${ }^{5}$ \\ ${ }^{1}$ North Pacific Fishery Management Council, Anchorage, AK 99501-2252 \\ ${ }^{2}$ Department of Economics, University of Alaska Fairbanks, Fairbanks, AK 99775-6080 \\ ${ }^{3}$ National Marine Fisheries Service, Alaska Fishery Science Center, 7600 Sand Point Way NE, Bldg 4, Seattle, WA 98115 \\ ${ }^{4}$ Department of Economics, Utah State University, Logan, UT 84322-3530 \\ ${ }^{5}$ Department of Natural Resource Management, University of Alaska Fairbanks, Fairbanks, AK 99775-7580
}

\begin{abstract}
Forecasts of the regional economic impacts of changes in the demand for recreation occasioned by regulatory changes, changes in the quality of the recreation experience, or changes in average trip costs
\end{abstract} require a model that links changes in these trip attributes to individual participation decisions and population participation rates. The probability that an individual will take a particular recreational trip is described using a nonlinear random effects probit model based on variable trip attributes and individual economic and demographic characteristics. These conditional individual probabilities are transformed into predictions of changes in total recreation demand using a simulation-based sample enumeration method. The regional impacts associated with ensuing changes in primary and secondary expenditure patterns are elucidated with a stand-alone recreation-sector module linked to a regionally adjusted zip code-level input-output model. Because the participation model allows for non-constant marginal utility, primary and secondary impacts exhibit nonlinear responses to variations in trip attributes. The modeling approach is demonstrated in an application to the saltwater sport fisheries for Pacific halibut and salmon in Lower and Central Cook Inlet, Alaska.

Please direct correspondence to Mark Herrmann, Department of Economics, University of Alaska Fairbanks, Fairbanks, AK 99775-6080. (email: ffmlh@uaf.edu) (Fax: 907-474-5219)

Partial funding for this project was provided by Alaska Sea Grant with funds provided under grant 98-403 R14-17 and from the Minerals Management Service through the University of Alaska Coastal Marine Institute project 12-35-0001-30661 task order 14196. The views expressed herein are those of the authors and do not necessarily reflect those of the institutions or agencies with which they are affiliated.

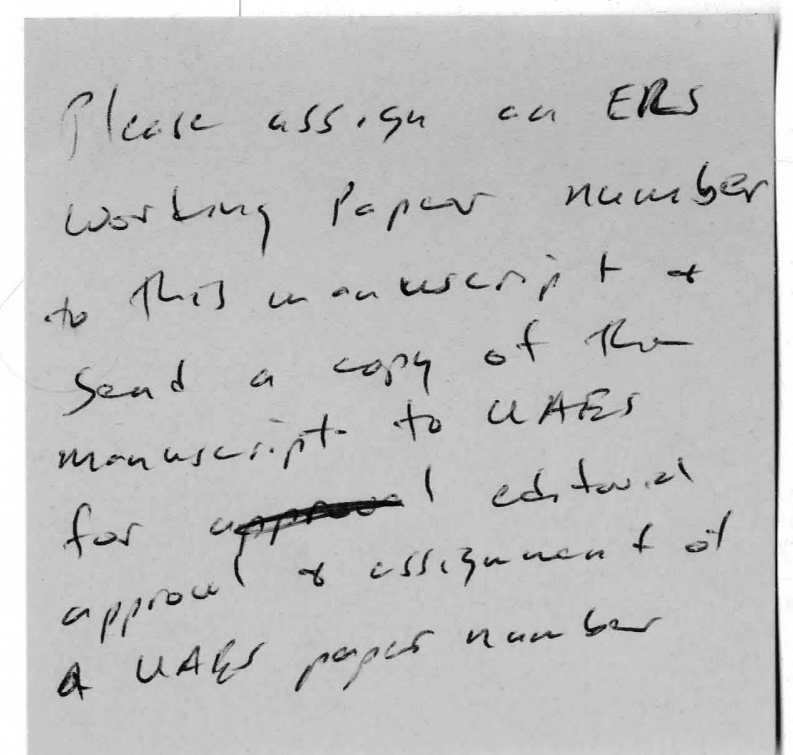




\section{Introduction}

The lure of world-class fresh and saltwater sportfishing opportunities makes Alaska's Kenai Peninsula one of the state's most visited regions. This study examines the regional economic impacts of expenditures related to the saltwater sport fisheries for Pacific halibut (Hippoglossus stenolepis), and chinook (Oncorhynchus tshawytscha) and coho (O. kisutch) salmon that take place in the marine waters of Lower and Central Cook Inlet. Most of these trips originate from road-accessible segments of the western shoreline of the Kenai Peninsula. In addition to non-monetary benefits enjoyed by visiting and resident anglers, sportfishing contributes to the economic well being of Kenai Peninsula communities as infusions of new money filter through tourism related businesses and circulate within local economies.

The decision to take a sportfishing trip is based on the expectation that the benefits of taking the trip will exceed the associated costs. Consequently, an understanding of how that decision depends on individual demographic characteristics and attributes of the recreation experience allows prediction of how angler behavior will change in response to changes in trip attributes. For example, changes in fish stock abundance that affect catch rates or regulatory measures that affect bag and possession limits will be perceived by anglers as changes in the attribute bundle associated with their fishing trip. By expressing the likelihood that alternative fishing trips will be taken in probabilistic terms, we can develop confidence bounds around estimates of changes in participation rates and associated changes in regional expenditures.

Examples of recent policy initiatives that highlight the need for regional impact analyses to account for the contribution of recreation activities include: damage assessments associated with the S.S. Glacier Bay and S.S. Exxon Valdez oil spills; potential risks associated with outer continental shelf petroleum development lease sales adjacent to prime commercial and recreational fishing grounds in Lower Cook Inlet and the Gulf of Alaska; and, management decisions to determine the allocations of allowable catches between commercial, sport, and subsistence fishers. Because oil exploration, development, and production activities in Cook Inlet could affect the productivity of adjacent fishing grounds and the 